\title{
Pulp and Paper Fiction: On the Discursive Legitimation of Global Industrial Restructuring
}

\author{
Eero Vaara \\ Swedish School of Economics and Business Administration, Finland/Ecole de \\ Management de Lyon, France \\ Janne Tienari \\ Lappeenranta University of Technology, Finland \\ Juha Laurila \\ Helsinki School of Economics, Finland
}




\begin{abstract}
Despite the central role of legitimacy in social and organizational life, we know little of the subtle meaning-making processes through which organizational phenomena, such as industrial restructuring, are legitimated in contemporary society. Therefore, this paper examines the discursive legitimation strategies used when making sense of global industrial restructuring in the media. Based on a critical discourse analysis of extensive media coverage of a revolutionary pulp and paper sector merger, we distinguish and analyze five legitimation strategies: (1) normalization, (2) authorization, (3) rationalization, (4) moralization, and (5) narrativization. We argue that while these specific legitimation strategies appear in individual texts, their recurring use in the intertextual totality of the public discussion establishes the core elements of the emerging legitimating discourse.
\end{abstract}

Key words: legitimation, discourse, media, industrial restructuring, globalization

'Legitimacy' and 'legitimation' play a central role in social action in general and organizational action in particular. In organization studies, legitimacy has been an important theme in several streams of research, but explicit analyses of legitimation are still scarce (e.g. Hybels 1995; Suchman 1995). We argue, in this paper, that there is a specific lack of knowledge concerning the discursive processes, practices, and strategies used to (re)construct senses of legitimacy/illegitimacy. Nevertheless, such knowledge is needed if we want to better understand the complex, but often subtle meaning-making processes through which organizational phenomena, such as industrial restructuring, are legitimated in contemporary society.

As a step in this direction, we concentrate in this paper on the discursive legitimation in the media. By adopting a critical discourse analysis (henceforth CDA) perspective and by drawing on previous work by linguists on legitimation (Van Leeuwen and Wodak 1999), we focus on discursive legitimation concerning industrial restructuring. Our aim is to develop an empirically grounded model that will serve organization scholars in trying to understand the micro-level discursive strategies used in legitimating contemporary organizational phenomena. We focus on the media as an 
important but still not very well-known legitimating arena for organizational phenomena. Our research question is the following:

What are the discursive strategies used when legitimating industrial restructuring in the media?

We are consequently not looking at whether specific changes at particular points of time are seen as legitimate by any stakeholder group. Instead, we focus on the subtle discursive strategies that tend to construct a sense of legitimacy around these phenomena in the public discourse.

In our analysis, we focus on a 'revolutionary' Finnish-Swedish merger that paved the way for a series of cross-border mergers and acquisitions, fundamentally changing the international paper and pulp industry. This case created a lively debate in the Finnish and Swedish media and thus serves as an excellent example of the micro-level discursive practices employed when making sense of, and giving sense to, the merger considered here and global industrial restructuring more generally. In our analysis, we single out and exemplify subtle discursive strategies used more or less intentionally by journalists. In our emerging model, we call them (1) normalization, (2) authorization, (3) rationalization, (4) moralization, and (5) narrativization. We argue that while these specific legitimation strategies appear in individual texts, their recurring use in the intertextual totality of the public discussion establishes the core elements of the emerging legitimating discourse.

To our knowledge, this is the first systematic attempt to outline a model of discursive legitimation strategies in the organizational context, and hence a contribution to the organization studies literature on legitimacy (e.g. Suchman 1995). In particular, we argue that looking at these kinds of micro-level discursive elements helps us to understand the complexities, ambiguities, and contradictions in legitimation, which easily pass unnoticed with more traditional approaches. By focusing on media texts, this study also makes a contribution to our understanding of the role of the media in the complex processes leading to the legitimation and naturalization of contemporary organizational phenomena, which is a topic that deserves special attention in organization studies (e.g. Mazza and Alvarez 2000). By concentrating on a merger case, this study specifically 
sheds more light on the discursive underpinnings of industrial restructuring and thus adds to our understanding of this important contemporary phenomenon (e.g. Vaara and Tienari 2002; Comtois et al. 2004). Moreover, being one of the very few empirically grounded analyses extending the pioneering work on discursive legitimacy (e.g. Van Leeuwen and Wodak 1999), our study also contributes to the theories of discursive legitimation more generally.

\section{Legitimation in Organizational Research}

The concept of legitimacy has had an important role in landmark sociological analyses (e.g. Berger and Luckmann 1966; Habermas 1975; Giddens 1984). Partly because of this, there is significant ambiguity concerning what legitimacy actually means and how it is linked with the various processes through which social reality is constructed. Although 'legitimacy' has been an important theme in several streams of research in organization studies (e.g. Dowling and Pfeffer 1975; Scott 1995), there are few analyses focusing explicitly on legitimation. It is primarily the institutionally oriented analyses, broadly defined, that have most explicitly advanced our understanding of legitimacy and legitimation in the organizational context (Hybels 1995; Suchman 1995).

As a result of these studies, we have learned that legitimacy is closely linked with power and that attempts to establish legitimacy are a key part of management (Dowling and Pfeffer 1975; Ashforth and Gibbs 1990). Analyses have shown that legitimacy — or better, senses of legitimacy - can rest on different bases: the pragmatic, meaning calculations involving self-interest; the moral, based on normative approval; and the cognitive, based on comprehensibility and taken-for-grantedness (Suchman 1995). From various studies, we also know that legitimation is intimately linked with institutionalization (Aldrich and Fiol 1994; Kostova and Zaheer 1999; Zimmerman and Zeitz 2002; Kitchener 2003). Hence, some kind of legitimacy is a prerequisite for the institutionalization of specific ideas, practices, forms, or changes. At the same time, institutionalization contributes to legitimacy in the sense that established and widely spread ideas, practices, or forms are easily considered legitimate and no longer require specific legitimation. In addition, recent research has focused attention on legitimation 
strategies, that is, on ways in which legitimacy is created (e.g. Kostova and Zaheer 1999; Zimmerman and Zeitz 2002). While such studies have greatly advanced our understanding of legitimation processes, they have not, however, gone very far in exploring and singling out various kinds of micro-level processes and practices creating senses of legitimacy/illegitimacy. Apart from being a deficiency per se, this has, in our view, prevented organizational scholars from making progress in conceptualizing legitimacy as a temporal, context-specific, ambiguous, and even contradictory phenomenon.

In particular, we still know relatively little about the discursive processes involved in legitimation. Studies drawing from different traditions have pointed to the central role of impression management in establishing legitimacy (Elsbach and Sutton 1992; Arndt and Bigelow 2000); shown how legitimation efforts can involve very targeted and even manipulative rhetoric (Brown 1995; Brown and Jones 2000); demonstrated how discursively established legitimacy is a central part of identity construction and stakeholder relations in inter-organizational settings (Hardy and Phillips 1998; Lawrence et al. 1999); and illustrated how legitimating accounts involve an adaptation of broader discourses to local needs (Creed et al. 2002; Vaara and Tienari 2002). While these and other studies have given us important insights into the discursive side of legitimation, they have not focused on the micro-level textual practices and strategies used to (re)construct senses of legitimacy/illegitimacy. In our view, this is unfortunate, as it is precisely these kinds of subtle textual means - which often pass unnoticed - that play a central role in legitimating particular organizational phenomena in specific arenas.

On the whole, organizational scholars have generally not paid much attention to the media as a sensemaking arena. In our view, this is regrettable given the crucial role of public discourse in constituting senses of legitimacy/ illegitimacy around contemporary organizational phenomena. Having said that, there are interesting empirical studies illustrating the central role of discursive elements in establishing legitimacy through the media. Researchers have, for example, shown how the media provide specific kinds of discursive resources — such as 'storyboards' - to help readers to make sense of, and thereby legitimate, specific ideas and practices (Watson 1998); how popular management literature offers different kinds of metaphoric bases for the understanding and subsequent 
legitimation of specific changes (Dunford and Palmer 1996); how the widespread legitimation in the popular press builds on conformity, social support, and narratives (Mazza and Alvarez 2000); how the form and content of the media texts change over time when specific ideas or practices are legitimated (Lamertz and Baum 1998); and how legitimation takes different forms depending on the discursive frames in question (Vaara and Tienari 2002). These studies have not, however, provided a systematic view of the micro-level discursive practices and strategies employed to legitimate contemporary organizational phenomena in arenas such as the media. This is why we now turn to CDA as a theoretical and methodological basis for an analysis of such discursive practices and strategies.

\section{Towards a CDA Perspective on Discursive Legitimation}

Discursive approaches have become increasingly popular in social science (e.g. Van Dijk 1997). This is also the case with organization studies (e.g. Grant et al. 1998, 2004; Alvesson and Kärreman 2000; Westwood and Linstead 2001; Phillips and Hardy 2002; Hardy et al. 2004). As is well known, there are, however, significant differences across various discourse-analytic approaches (e.g. Phillips and Hardy 2002). One important division relates to the ontological/epistemological understanding of the relationship between language and social reality: whether the focus is solely on language or whether language is seen as one (central) part of social reality. Another important division exists between those approaches that take a more neutral perspective on the social phenomena in question and those that adopt a more critical one.

CDA can be defined as a discourse-analytic methodology that examines the role played by language in the construction of power relationships and reproduction of domination. There are, however, different traditions in CDA. Fairclough and Wodak (1997: 262-268) distinguish French discourse analysis, critical linguistics, social semiotics, socio-cultural change and change in discourse, socio-cognitive studies, discourse-historical method, reading analysis, and the Duisburg school, as important streams of research. Our analysis draws particularly on the work of Norman Fairclough on socio-cultural change and change in discourse $(1997,2003)$ and the discourse- 
historical method of Ruth Wodak and her colleagues (Wodak et al. 1999; Wodak and Meyer 2002), as they are both methodologically suitable and exhibit a close relationship to our interest in industrial and organizational change.

The following five features are essential in our version of CDA. First, CDA aims at revealing taken-for-granted assumptions on social, societal, political, and economic spheres and examines power relationships between various kinds of discourses and actors. In a sense, CDA attempts to make visible problems that often pass unnoticed. Second, contextuality is a key issue in CDA. Accordingly, Fairclough argues that discourses should be studied at three levels of analysis: textual (micro-level textual elements), discursive practices (the production and interpretation of texts), and social practice (the situational and institutional context). The discourse-historical method of Wodak, in turn, emphasizes the importance of the historical dimension in such analysis by maintaining that the emergence of specific discourses always takes place in a particular socio-historical context.

Third, intertextuality is also particularly important. In brief, one cannot fully comprehend specific texts or discursive acts without linking them with others. Fourth, related to the previous points, discourses are not neutral with respect to ideological content. Although the concept of 'ideology' can be understood in different ways, it is clear that specific discourses are linked with and (re)produce particular ideologies and hegemonies (Van Dijk 1998). This is sometimes readily observable, while at other times it is the implicit assumptions or the 'unsaid' elements in the texts that best reveal underlying ideologies and hegemonies.

Fifth, all these requirements and the inherent complexity of meanings imply an interdiscursive approach to understanding the discursive construction of specific social phenomena. Fairclough (2003) outlines an approach where a text is seen as a composition of genres (various conventional ways of acting in its discursive aspect), discourses (distinctively different ways of representing aspects of the world), and styles (characteristic ways of being or identities in their linguistic aspect). Such an approach leads ideally to an understanding of 'orders of discourse', that is, ensembles of relationships between discourses, genres and styles in particular social contexts (Foucault 1980; Fairclough 2003). 
What does our CDA perspective, then, mean when studying discursive legitimation? From this perspective, legitimacy means a discursively created sense of acceptance in specific discourses or orders of discourse. The key point, here, is that it is the discourse and its characteristics that define what can be considered as legitimate/illegitimate. For example, from a neoliberal ideological perspective, most industrial restructurings make sense if they 'create shareholder value', while from a nationalistic perspective they may seem like the surrender of 'national heritage' to 'market forces' or 'foreign powers'.

What is important is that the CDA perspective allows one to shift attention from established legitimacy to the processes of legitimation by examining the concrete discursive practices and strategies used. In its simplest form, this means that specific actors try to persuade and convince others through various kinds of rhetorical moves. Particular things come to be portrayed as positive, beneficial, ethical, understandable, necessary, or otherwise acceptable to the specific community in question. In contrast, other things are constructed as negative, harmful, intolerable, or, for example, morally reprehensible. However, in settings such as the media, these processes are more complex as they also include journalists as editors of messages and texts.

These discursive processes also involve a political dimension. In most social settings, this means various and often ongoing socio-political struggles for legitimation, delegitimation, and relegitimation in different social arenas, such as the media. From this perspective, it is important to emphasize that legitimation not only deals with the specific phenomenon, action, or practice in question, but is also linked to the power position of the actors. For example, the legitimation of specific political actions endorses the leadership of the politician in question (e.g. Rojo and Van Dijk 1997). Likewise, the legitimation of specific strategic moves - for instance, a merger or an acquisition made by a corporation also legitimates the power position and leadership of the corporate management.

While there are various ways to examine the discursive processes of legitimation, Theo van Leeuwen and his colleagues have probably gone furthest in developing 'a grammar of legitimation' that distinguishes between and elaborates on specific legitimating practices (Van Leeuwen unpublished manuscript; Van Leeuwen and Wodak 
1999). These legitimation strategies are specific, not always intentional or conscious, ways of employing different discourses or discursive resources to establish legitimacy. According to Van Leeuwen, there are four general types of semantic-functional category. 'Authorization' is legitimation by reference to the authority of tradition, custom, law, and persons in whom institutional authority of some kind is vested. 'Rationalization' is legitimation by reference to the utility of institutionalized social action, and to the knowledge that society has constructed to endow them with cognitive validity. 'Moral evaluation' is, in turn, legitimation by reference to specific value systems. Finally, 'mythopoesis' is legitimation conveyed through narratives. Each of the four general types of semanticfunctional category includes a number of sub-types.

It should be noted that Van Leeuwen's model is a general one and has not been developed for legitimation in contexts such as the media, where specific journalistic practices greatly influence language use and where a particular kind of intertextuality plays a key role (e.g. Van Dijk 1990; Fairclough 1995; Bourdieu 1998). As to the journalistic practices, journalists act as gatekeepers and editors of messages. They have a great deal of power to decide what issues to raise, which perspectives to take, whom to give voice to, which voices to marginalize, and what to leave unsaid. This power should not, however, be overestimated, as the journalists are themselves dependent on both their information sources and their audiences. Accordingly, Bourdieu (1998) has argued that the media are forced to 'banalize' or speak of 'commonplaces', meaning that the media often reproduce what the audience already knows and wants to hear. As to intertextuality, the media coverage of events such as cross-border mergers and acquisitions usually involves a great deal of references across different texts. More specifically, various announcements, reports, and comments tend to create a dynamic where individual texts can hardly be understood without reference to others. While Van Leeuwen's model serves as an important reference point, it cannot thus be used straightforwardly as a theoretical framework in the media context. It is therefore the purpose of our empirical analysis to produce an empirically grounded model of the discursive strategies employed to legitimate industrial restructuring in the media.

\section{The StoraEnso Case}


To explore legitimation strategies, we now turn to international mergers and acquisitions as a specific form of contemporary industrial restructuring. Our empirical research project has focused on several pulp and paper sector merger and acquisition cases. In this analysis we will, however, focus on the merger between the Finnish Enso and the Swedish Stora.

The Finnish Enso (founded 1872; annual sales $€ 4.9$ bn; 19,900 employees) and the Swedish Stora (founded 1288; annual sales $€ 5.1$ bn; 20,400 employees) announced their intention to merge on 2 June 1998. This was the first large-scale cross-border merger in the paper and pulp industry (Laurila and Ropponen 2003), and it created a great deal of public attention, especially in Finland and Sweden. What is particularly interesting in this case is that, for many, it was an unthinkable union. On the one hand, these Finnish and Swedish paper companies had traditionally been arch-rivals. On the other, Stora, which was owned by the Wallenberg family, and the state-owned Enso appeared to be a strange match. After a lively public debate, the merger won the support of the Finnish parliament, which was necessary due to the state's holding in Enso. The EU Commission approved the merger in November 1998.

The StoraEnso merger is a particularly suitable case for our purposes. First, the merger was an unprecedented case, creating a great need to make sense of what was happening and to legitimate the changes taking place. Second, it created an intensive discussion in the Finnish and Swedish media, thus providing ample material for an analysis of different types of discursive legitimation strategies. Third, the merger was in many ways controversial, not least because it united the Wallenberg-owned Stora and state-owned Enso. This created a special need for legitimation and a basis for an interesting legitimation-delegitimation-relegitimation dynamic. Fourth, the merger proved to be a pioneering case, as it was followed by a wave of cross-border mergers and acquisitions between the leading Finnish, Swedish, and American corporations in 19982000. It can thus be seen as a 'turning point' case in terms of paving the way and setting the discursive stage for the legitimation of the restructurings that followed. Fifth, the merger later received harsh criticism, particularly because of problems in creating the 'promised' synergies, making it a particularly fitting case for critical analysis. 


\section{Methodology}

We gathered extensive media material both in Finland and Sweden. We included leading daily newspapers, leading business news outlets, and local papers (selected on the basis of the location of the mills) in our material. Table 1 provides a summary of the media coverage during the period 2 June-2 July 1998.

$\mathrm{CDA}$ is by its very nature abductive; that is, 'a constant movement back and forth between theory and empirical data is necessary' (Wodak 2004: 200). This is also the case with our analysis, where we have conducted increasingly focused empirical analyses while refining our theoretical ideas concerning discursive legitimation. As is usually the case with CDA, it is very difficult to report all the rereading and reinterpretation steps. Retrospectively, we can, however, distinguish three important stages in our analysis: a thematic analysis of the media material, an interdiscursive analysis distinguishing different discourse types used in legitimation, and a textual analysis focusing on the most important legitimation strategies.

We began with a thematic analysis, which is arguably a recommended way to start any critically oriented media analysis (e.g. Vaara and Tienari 2004). This led to an understanding of what kinds of issues were discussed in the StoraEnso case and what kinds of topics seem to be brought up more generally when dealing with global industrial restructuring. The most important themes included price, ownership, synergy and other benefits, staff reductions, cultural differences, and division of management positions and responsibilities. At this stage, we also narrowed down our material by singling out those pieces of texts that were most relevant for our analysis. This meant removing more 'factual' news-like pieces of texts from our material.

At the second stage, we proceeded by an interdiscursive analysis, focusing on the various discourses used when dealing with these themes. This kind of analysis, helping to understand the 'order-of-discourse' in the texts in question, is a crucial part of any CDA study (e.g. Fairclough 2003; Wodak 2004). In brief, we distinguished 'neoliberal' (linked to the ideology of neoliberalism), 'nationalistic' (linked to nationalist ideology), 'humanistic' (a more critical discourse linked to particular kinds of humanism, 
exemplified by unemployment concerns), and 'entertainment' discourse (a particular mix of company- and personal-level dramas) types. In most texts, these discourses were intertwined and blended. However, the neoliberal discourse type was

Table 1 Empirical material

\begin{tabular}{|l|l|l|}
\hline Outlet & Description & $\begin{array}{l}\text { Number } \\
\text { of articles }\end{array}$ \\
\hline Helsingin Sanomat (HS) & $\begin{array}{l}\text { Leading Finnish } \\
\text { daily newspaper }\end{array}$ & 30 \\
\hline Ilta-Sanomat (IS) & $\begin{array}{l}\text { Leading Finnish } \\
\text { daily newspaper }\end{array}$ & 25 \\
\hline Kauppalehti (KL) & $\begin{array}{l}\text { Leading Finnish } \\
\text { daily business } \\
\text { newspaper }\end{array}$ & 20 \\
\hline Etelä-Saimaa (ES) & $\begin{array}{l}\text { Daily newspaper in } \\
\text { Lappeenranta, } \\
\text { Finland }\end{array}$ & 28 \\
\hline Dagens Nyheter (DN) & $\begin{array}{l}\text { Leading Swedish } \\
\text { daily newspaper }\end{array}$ & 30 \\
\hline Svenska Dagbladet (SD) & $\begin{array}{l}\text { Leading Swedish } \\
\text { daily newspaper }\end{array}$ & 30 \\
\hline Falukuriren (FK) & $\begin{array}{l}\text { Daily newspaper in } \\
\text { Falun, Sweden }\end{array}$ & 26 \\
\hline Total & & 189 \\
\hline
\end{tabular}

by far the most dominant discourse in terms of both frequency and its dominant role visà-vis other discourse types. This was not, as such, surprising given the results of our previous research on mergers and acquisitions (Vaara 2002; Vaara and Tienari 2002).

These discourses provided very different kinds of means for framing specific issues and for establishing legitimacy. In principle, any discourse type could be used for legitimation or delegitimation purposes but they were often combined or used in specific ways. In particular, most of the legitimation involving some references to authorities or explicit rationalization drew from the neoliberal discourse. We also saw that attempts to criticize or delegitimate the deals most often implied reverting to other discourses, most notably nationalistic or humanistic ones, providing a completely different kind of moral 
or ideological basis from the neoliberal discourse. In addition, we found that the entertainment discourse was an important part of the media coverage, which led us later to elaborate on how this entertainment side is linked with legitimation by narrativization.

At the third stage, we then proceeded by carrying out a textual analysis of the legitimating strategies. Moving toward an increasingly targeted textual analysis is, overall, recommended in CDA (e.g. Wodak 2004). In our case, this was necessary to understand how specific discourses were used in actual practice for legitimating or delegitimating purposes. We focused on the texts authored by journalists and on their discursive strategies, not on the strategies employed by other social actors such as the protagonists or antagonists of the mergers and acquisitions per se. However, taking an intertextual perspective on media texts inevitably means that one is dealing not only with journalists as authors, but also with the voices of the protagonists or antagonists as reproduced in the texts authored by the journalists.

We analyzed and categorized the legitimation strategies used in the media texts on the basis of their frequency and strategic importance in the textual material. We used Van Leeuwen's ideas when making sense of and categorizing our research findings. However, rather than simply analyzing textual strategies per se, we linked them with journalistic practices. This led to the distinguishing of five types of legitimation strategy: 'normalization', 'authorization', 'rationalization', 'moralization', and 'narrativization'. We then went on to refine our categorizations and to distinguish specific sub-categories of specific legitimation strategies, as reported in the following sections. Finally, we analyzed the various forms of multiple legitimation in more detail.

\section{The Discursive Legitimation Strategies Normalization}

In Van Leeuwen's model, legitimation by reference to normal or natural functioning or behavior is not considered a separate category of legitimation. In his model, 'conformity legitimation', dealing with custom and tradition, is a sub-type of authorization, and 'factof-life rationalization' or 'naturalization' is a sub-type of rationalization. However, in our view, rendering something normal or natural requires special recognition as a specific category of 'normalization'. This normalization can actually be seen as the primary type 
of legitimation, as it seeks to render something legitimate by exemplarity. This exemplarity can involve 'retrospective' (similar cases/events/practices in the past) or 'prospective' (new cases/events/practices to be expected) references, both of which are important in rendering the case at hand as something 'normal'.

In our material, journalists typically first constructed the StoraEnso case as dramatic news, for example with catchy titles. In the texts, they then often placed the case in the context of carefully selected examples of similar maneuvers, thus establishing conformity and continuity. Interestingly, there were no similar large-scale cross-border mergers that could have been referred to in the pulp and paper industry. Hence, journalists tended to refer to cases in other industries. The following are typical examples from Finland and Sweden:

'In a merger of this magnitude, it is clear that the whole world is considered as the market. In terms of its consequences for competition, the union of Enso and Stora is thus comparable to the mergers between the automobile giants Daimler Benz and Chrysler as well as Boeing and McDonnell Douglas in the aviation industry.' (Helsingin Sanomat, 3 June 1998) ${ }^{1}$

'After Merita-Nordbanken, Chrysler-Benz, Segram-Polygram it was time for forestry companies Stora and Enso to join hands. The bigger the company, the easier it is to forcefully take markets, business leaders reason. Tuesday's giant merger pleased the owners but left the employees worried.' (Dagens Nyheter, 3 June 1998)

These texts construct the paper and pulp industry as similar to other industries in terms of its dynamics of competition. This is, however, in contrast to the conventional view, which emphasizes the specific and unique features of the pulp and paper industry. The journalists in question also draw parallels between Enso and Stora and US- and Germany-based multinationals, which are characterized by completely different histories and ownership structures. This is interesting in view of the fact that the merger meant a

1 Texts in Finnish and Swedish have been translated by the authors and checked by a Finnish-speaking native English speaker. 
radical transformation of both Enso and Stora. Especially the transformation of Enso, from a state-owned company into a multinational publicly listed company, was a major change - one that required specific legitimation.

Such exemplification could also mean projections into the future, as in the following:

'It is expected in London that the consolidation in the forestry sector will continue, and that the next move is in Europe by MoDo, Metsä-Serla or Norske Skog.' (Kauppalehti, 3 June 1998)

Note that this example also involves authorization when referring to a specific authority (London) as well as a particular kind of predictive narrative structure. We will discuss these other types of legitimation below, but can readily conclude that normalization was often combined with other discursive legitimation strategies.

\section{Authorization}

Authorization is legitimation by reference to authority. These authorities can be the journalist him/herself, someone in whom institutionalized authority is vested, or impersonal, for example, laws, regulations, or conventions. In our material, the texts often referred to authorities such as the corporate representatives, the 'markets', analysts, industry experts, and competition officials, when legitimating or delegitimating the merger or acquisition cases in question.

While a close reading of specific texts could reveal a number of authorities, it is important to point to the key role of the 'markets', an essential nominalized part of neoliberal world order, in this case. Typical examples of authorization drawing on the markets were expressions like 'according to the markets' or 'the markets estimate'. Note how the inanimate/impersonal noun 'markets' is personified, giving attributes of persons to the markets (such as a capacity to 'estimate'). 
More specifically, particular analysts such as stockbrokers or investors' representatives emerged as key commentators in our media material. These actors can be seen as 'fast-thinking experts', to use Bourdieu's (1998) vocabulary. In fact, reference to their views was a general discursive strategy that the journalists employed when discussing global restructuring in the industry. Typical examples of such authorization were expressions such as 'analysts believe' or 'analysts estimate'.

In national and local broadsheet newspapers, it was also typical to refer to wellknown figures to legitimate specific cases. Jaakko Pöyry, the Finnish technology and management consultant group specializing in forestry, is a focal example. It seems that the market studies and prognoses by Jaakko Pöyry were easily accessible sources for journalists to ponder on industry dynamics, as in the following:

'In the cover story of Kauppalehti Optio on November 11th 1997, Jaakko Pöyry estimated that consolidation will lead in the next few years to around ten global forestry companies, including both Finnish and Swedish companies.' (Kauppalehti, 11 June1998)

From a critical perspective, it should be noted that analysts or experts, such as Jaakko Pöyry, are not neutral commentators on industrial restructuring. They have vested interests in the discussions, as they are often in some way involved in the deals discussed.

While 'markets', 'analysts', and 'experts' served as legitimating authorities, journalists referred frequently to competition officials and politicians for delegitimating purposes. Interestingly, competition officials in particular were frequently constructed in a way that could be interpreted to question or undermine their authority, as in the following (our italics):

"EU competition officials should in fact say "no" to the deal, especially if one considers the way they make trouble with a whole lot smaller companies.' (Falukuriren, 3 June 1998) 
In the more lengthy commentaries, journalists also employed the technique of contrasting different voices, for example, those of corporate representatives, industry experts, competition officials, and workers' representatives. By referring to these diverse authorities, journalists could thus highlight the complex and even contradictory implications of these deals. We will return to this strategy in the section on 'moralization'.

While we have pointed to specific authorization strategies in individual texts, it should be noted that, in the intertextual totality, specific authorizations seemed to grow into established practices. In particular, specific analysts or industry experts were given an institutionalized role as frequently used commentators. In contrast, alternative voices such as employees' representatives or anti-globalization figures were rarely given such an authority position.

\section{Rationalization}

Rationalization is legitimation by reference to the utility or function of specific actions or practices. While there are different forms of rationalization, we concentrate on 'instrumental rationalization'. In our context, this instrumental rationalization focuses on the benefits, purposes, functions, or outcomes that global restructuring creates at company and industry levels. In our case, these rationalizations were primarily of the economico-financial type - linked to the ideals of neoliberalism. More specifically, 'growth', 'economies of scale', 'efficiency', 'synergy', and 'shareholder value' served as the most frequently used rationalizations.

In this context of large-scale structural arrangements, the question was usually about relatively abstract benefits achieved by integrating the merging or acquired corporations. The benefits were objectified and factualized, for example, in the following way:

'With the merger, the companies are searching for cost savings. These are expected, for example, in streamlining production, plant specialization, combined 
purchasing and transportation, and coordinated investment policy. (Etelä-Saimaa, 3 June 1998)

Rationalizations typically involved specific financial figures that were derived from calculations made by corporate representatives or their advisers:

'Synergy benefits will not be too difficult to find. SEK 500-800 million was mentioned yesterday. It is possible that the promised annual target of nearly SEK 2 billion in savings can be realized before the end of 2002.' (Dagens Nyheter, 3 June 1998)

It should be emphasized that these kinds of statements were based on estimates of the abstract benefits to be realized by integrating the operations of the companies. An illuminative example of the relativity and ambiguity of synergy benefits is that, once StoraEnso's profitability declined after the initial merger announcement in 1998, corporate representatives were quick to publicize figures for future synergies, which would be significantly higher than those estimated six months earlier. It needs to be stressed that it is very difficult for outsiders to criticize such calculations. This is because, typically, only corporate representatives have access to all the information required to make (apparently) accurate estimates and calculations concerning, for example, synergy benefits.

It is important to note that these, like all rationalizations, were based on specific moral and ideological grounds. As in the examples above, the merger was most often rationalized within the framework of neoliberalism. This was shown most explicitly in an extensive discussion around the share prices as well as rhetorical choices such as emphasizing 'shareholder value' above anything else. Alternative rationalizations and moralizations could be used for delegitimation purposes, and we will turn to them in the following section.

\section{Moralization}


Moralization is legitimation that refers to specific values. As noted above, rationalization always has a moral basis, although not always an explicit one, and therefore it is questionable whether these two strategies actually form two different legitimation categories. In our material, an explicit moralization strategy was most visibly used for delegitimation purposes. However, even in these cases, the texts were rarely openly moralistic, but rather reflected a specific value basis that differed significantly from that of neoliberalism. More specifically, when the journalists wanted to question the legitimacy of the merger or global industrial restructuring more generally, they often reverted to nationalistic (emphasizing the national interests as the key value) or humanistic (prioritizing the interests of the employees) discourses.

As an example of nationalistic moralization, the discussion on turning the stateowned Enso into a multinational company involving majority foreign ownership is particularly interesting. The Finnish state was a majority shareholder in Enso at the time of the announcement of the merger with Stora. Stora was, in turn, controlled by the Wallenberg family dynasty of Sweden. This was a match that triggered a great deal of public discussion in Finland, involving strong criticism. For example, Helsingin Sanomat $(H S)$ ran a series of articles where the antagonists and protagonists debated whether the merger was in the Finnish national interests. The following is a typical example where an antagonist (the chairman of the leading opposition party) was given an opportunity to question the moral basis of the merger:

'The people behind this decision have to answer to the question of why the Swedish Wallenberg family or American institutional investors are better and more trustworthy owners of the Finnish forest industry than hundreds of thousands of Finnish forest owners in the countryside or the cities.' (HS, 9 June 1998)

However, these delegitimating moralizations were often followed by relegitimating commentaries. In these comments, the protagonists frequently portrayed the internationalization of the Finnish forest industry as a 'must' or a 'moral duty' for the Finnish decision-makers. 
As an example of humanistic moralization, the negative implications for Falun, as the former headquarters of Stora, were discussed extensively from a critical perspective in Sweden. In particular, the local Falukuriren $(F K)$ ran a series of articles discussing the removal of the headquarters from Falun (Sweden) to Helsinki (Finland) and the consequent job losses. These articles questioned the moral basis of the merger, but also the implications of global industrial restructuring more generally. The following is a typical example:

'First Falun mine was closed. Now the headquarters moves away from the region. Seven hundred years of history in Falun and Dalar is heading towards its unavoidable end. "This is very unfortunate," states Kenneth Hindsberg, a representative for the local union in a strong local dialect.' ( $F K, 3$ June 1998)

In this text, the merger is linked with a previous controversial decision to close the Stora mine in Falun, creating a cloud of suspicion over the merger decision. Note that these texts were among the very few giving employees and union representatives an explicit voice and a chance to criticize the merger.

Such delegitimation was, however, often countered by relegitimation strategies. For example, in dealing with the issue of job losses in the Falun region, the ex-CEO of Stora was given space for the following comment:

'There are going to be some effects, but I do not think that they will be too dramatic, says Björn Hägglund. Worldwide we have overcapacity of perhaps 500 white-collar people, but it is difficult to say what this implies for Falun.' ( $F K, 3$ June 1998)

Note the evasive tone here. Even though this is one of the few examples mentioning concrete numbers, only white-collar workers are considered and the implications for Falun - where most of the reductions will presumably be made — are not specified.

The moral concerns could also be dismissed by reverting to neoliberal discourse. In an illuminating example, after discussing the moral concerns of surrendering the 
control of Stora to foreign hands and the associated job losses, Falukuriren concluded that: 'Emotions are one thing. Economic reality is another' ( $F K, 3$ June1998).

\section{Narrativization}

Finally, the texts also involved narrative-type reconstructions. Van Leeuwen has emphasized the mythopoetic side of legitimation: how telling a story provides evidence of acceptable, appropriate, or preferential behavior. Fairclough (2003: 99), in turn, has shown that mythopoesis can also involve some forms that are not narratives in their strictest pre-genre or genre sense. In our material, for example, the future projections (see Normalization above) can be seen as particular kinds of pre-narrative legitimation strategies. However, here we want to pay specific attention to 'dramatic narrativizations', where particular companies or persons were portrayed as winners, losers, heroes, adversaries, or culprits. The texts in question were often entertaining in tone and thus attracted readers in a special way.

Most of the longer articles construed industrial restructuring as a drama where the companies were competing against each other. Interestingly, in these articles, restructuring was portrayed as an inescapable objective and the drama was all about who was going to emerge as the winner or loser. At the textual level, this was shown in modality typically characterizing the texts; global industrial restructuring was 'inevitable'.

The texts typically included a brief sketch of the history of the companies, usually crafted so that the merger became the culminating point or climax. As an illustrative example of longer histories, Falukuriren (3 June1998) ran a story on Enso under the title: 'The history of Enso - The war caused damage'. The text started by making the point that it was a Norwegian who had made the first investments. It then went on to describe the various hardships encountered in turning Enso into a leading international pulp and paper company. The text ended by stating that: Now Enso is number five in the world and will become number one when merged with Stora.' As a result, the reader was left 
with an impression that the Finnish-based company had finally made it to the top — with Nordic help.

One day later, Falukuriren ran a story entitled '1000 years of enormous deals' on the history of Stora (FK, 4 June1998). The article started by saying: 'The merger between Stora and the Finnish Enso is a culmination point in the 1,000 year history of Stora's international deals.' The text then described the most dramatic acquisitions made during different periods. The article ended by stating: 'However, foreign minority owners have always been a part of the history.' Reading the text leaves the unavoidable impression that mergers and acquisitions had always been part of Stora's history and that foreign ownership was not something new either.

In many stories, Stora, Enso or StoraEnso were competing with their rivals. For example, Svenska Dagbladet (3 June 1998) ran a long story entitled 'The merger makes StoraEnso the biggest of them all'. According to the text, StoraEnso, due to its successful mergers and acquisitions, was construed as the winner of the global restructuring game. Explicit references to production capacity, annual turnover, and market value were frequent — just as in numerous similar reconstructions.

However, the Finns and Swedes were often portrayed as rivals and the focus was on whether Enso (in the Finnish media) or Stora (in the Swedish media) would emerge as the winner in the merger. Depending on the perspective, stories could be constructed in different ways. For example, when it came to ownership and share prices, Stora was usually portrayed as the winner: e.g. 'Stora beat Enso in the merger negotiations' $(H S, 17$ June 1998). In contrast, in the division of top management positions, it was the Finns who were seen as the victors (e.g. Ilta-Sanomat, 9 June 2004). Moreover, such articles often involved intertextual references to other Finnish-Swedish mergers and even to international sports competitions between Finns and Swedes, underscoring the nationalistic importance of the merger.

It was also typical that the journalists personified these dramas by focusing on the key managers and giving them 'celebrity' status (see also Fairclough 1995). This is probably best exemplified by the media coverage of the appointment of Enso's Jukka Härmälä as the new CEO for StoraEnso. Helsingin Sanomat wrote the following the day after the announcement: 'Jukka Härmälä will become the king of the forestry industry in 
Europe' (HS, 3 June 1998). Many others followed suit. Ilta-Sanomat ran an article titled 'Big, bigger, Jukka Härmälä' (IS, 9 June1998). There was a play on words in the original Swedish-language title, 'Stor, större, Jukka Härmälä', in the Finnish-language paper (the company name Stora means 'big' in Swedish). The text began: 'Who would still believe that size doesn't matter? In the forest industry, this idea is long forgotten. The trend is towards bigger and bigger units.' The body of the article included a glorified overview of Härmälä's impressive career. On the whole, in this and other texts, Härmälä's example was frequently seen as a Finnish victory in the competition between the Finns and the Swedes, thus legitimating the merger from a nationalistic perspective.

In all, narrativization contributed to the legitimation of cross-border mergers and acquisitions, by reinforcing a structure where such maneuvers were portrayed as natural objectives for the companies. It should be emphasized that while narrativization served as an important legitimating strategy in its own right, it often provided an overall frame that supported the other types of legitimation discussed earlier.

\section{Discussion: A Model of Discursive Legitimation}

In this paper, we have focused on developing an empirically grounded model of discursive strategies used in legitimating contemporary organizational phenomena such as radical industrial restructuring in the media. This model is summarized in Table 2. Although the particular discursive features that we have focused on in our empirical analysis on industrial restructuring are context-specific, we argue that the legitimating strategies revealed in the analysis are also likely to characterize other settings. Consequently, we feel that this model can help organization scholars to better understand the discursive underpinnings of legitimation when it comes to other important contemporary organizational phenomena.

Four points should be emphasized when considering these discursive strategies. First, although journalists construct the texts, the use of specific legitimating strategies is not likely to be fully intentional or conscious. As illustrated by our examples, journalists, like other human beings, are strongly influenced by the prevailing dominant discourses and available discursive practices. In the field of business journalism, the dominance of 
the neoliberal discourse is a fact (e.g. Bourdieu 1998; Fairclough 2000). It has become natural to discuss mergers and acquisitions within such discursive frameworks.

Table 2 A model of discursive strategies used to legitimate contemporary organizational phenomena

\begin{tabular}{|l|l|l|l|}
\hline & Individual texts & Intertextual totality & Power implications \\
\hline Normalization & $\begin{array}{l}\text { Exemplifies 'normal' } \\
\text { function or behavior }\end{array}$ & $\begin{array}{l}\text { Establishes recurring } \\
\text { examples }\end{array}$ & $\begin{array}{l}\text { Institutionalization of } \\
\text { specific examples }\end{array}$ \\
\hline Authorization & Authorizes claims & $\begin{array}{l}\text { Establishes recurring } \\
\text { authorizations and } \\
\text { authorities }\end{array}$ & $\begin{array}{l}\text { Institutionalization of } \\
\text { specific authorities } \\
\text { and marginalization } \\
\text { of others }\end{array}$ \\
\hline Rationalization & $\begin{array}{l}\text { Provides the rationale } \\
\text { Mostablishes recurring } \\
\text { rationalities }\end{array}$ & $\begin{array}{l}\text { Institutionalization of } \\
\text { specific rationalities }\end{array}$ \\
\hline Moralization & $\begin{array}{l}\text { Provides the moral } \\
\text { and ideological basis }\end{array}$ & $\begin{array}{l}\text { Establishes recurring } \\
\text { moralities and } \\
\text { ideologies }\end{array}$ & $\begin{array}{l}\text { Institutionalization of } \\
\text { specific moralities } \\
\text { and ideologies }\end{array}$ \\
\hline Narrativization & $\begin{array}{l}\text { Provides a narrative } \\
\text { structure to } \\
\text { concreticize and } \\
\text { dramatize }\end{array}$ & $\begin{array}{l}\text { Establishes recurring } \\
\text { narrative and drama } \\
\text { structures }\end{array}$ & $\begin{array}{l}\text { Institutionalization of } \\
\text { specific kinds of } \\
\text { narratives and } \\
\text { dramas }\end{array}$ \\
\hline
\end{tabular}

In fact, in the conditions of asymmetrical information, time pressure, and limited space available, it must be difficult for journalists to take a step back and try to go beyond the readily available discursive practices such as the talk around growth, economies of scale, or synergies. Consequently, journalists can easily become agents of legitimation or relegitimation fed by corporate communication departments, without being aware of the reasons for and consequences of their actions and without a grasp of the totality of which they are a part.

qSecond, as illustrated by several examples above, discursive legitimating strategies are often intertwined. For example, normalization seems to be strongly supported by other 
practices, especially by narrativization. Authorization appears to be linked with rationalization and moralization, not least because the authorities themselves usually (symbolically) represent specific institutions and viewpoints. Rationalization is always based on some moral and ideological basis, although this is not usually stated explicitly. Moralization is often an attempt to put authorizations and rationalizations into a particular legitimating or delegitimating perspective. Finally, narrativization is a specific means for giving concrete meaning to the rational or moral bases of the phenomenon at hand. In fact, as our examples show, multiple legitimation - drawing simultaneously on several legitimating strategies - seems to be particularly powerful.

Third, although in our material the journalists on the whole seemed to take strong stands in favour of radical industrial restructuring, it should be emphasized that media texts are often characterized by ambiguity and contradiction. Playing with multiple perspectives and contrasting rationalities and moralities is a traditional journalistic practice. This means that individual texts, not to speak of intertextual totalities, often involve both legitimating and delegitimating elements. This might be seen as something that reduces the power of the media in shaping public opinion. In our view, this is not necessarily the case. Contrast is something that readers have come to expect in media texts, and something that arguably increases the credibility of the news or commentary in question. Journalists often seem to play around with the negative and morally questionable aspects of industrial restructuring only to conclude that in the 'bigger picture' cross-border mergers and acquisitions are in the interests of a vast majority of stakeholders.

Fourth, while it is interesting to examine the use of specific strategies per se, it is of particular importance to emphasize the self-constitutive force of the emerging legitimating discourse in the intertextual totality. Our analysis clearly shows how specific legitimating strategies grew into established elements of the discourse around this case. We can see how specific examples, authorizations, rationalizations, moralizations and drama settings became widely used in the discussions around the StoraEnso merger. Experts such as the consultancy Jaakko Pöyry rose to a prominent position in authorizing the restructuring trend. Synergies, ironically often ambiguous and vague, became rationalizations cited in some way in numerous articles. Critical voices were at times 
heard but, on the whole, the logic and moralization of global capitalism tended to override other moralizations. Finally, dramas were constructed and reconstructed around the merging companies and the key people involved, creating an image of an inevitable restructuring game.

\section{Conclusion}

We have written this article primarily for organization scholars, and argue that it makes three specific contributions to organization studies. First, studies on organizational legitimacy have so far paid little attention to the discursive dimension (e.g. Suchman 1995). This is, to our knowledge, the first systematic attempt to outline a model of discursive legitimation strategies, and hence a contribution to our understanding of the legitimation of contemporary organizational phenomena. We feel that we have specifically made the case that, looking at these micro-level discursive elements helps us to understand the complexities, ambiguities, and contradictions of legitimation processes that easily pass unnoticed with more traditional approaches.

Second, although there are exceptions (e.g. Mazza and Alvarez 2000), organizational scholars have on the whole paid little attention to the media as a sensemaking and legitimation arena. This is also the case with studies on organizational discourse. The present analysis helps to understand the role of the media in the complex production, transmission, and consumption processes that create senses of legitimacy/illegitimacy around specific organizational phenomena. We also believe that our CDA perspective serves as a useful basis when proceeding with more fine-grained critical analyses concerning discursive legitimation in and through the media.

Third, as we have focused on industrial restructuring, this study specifically adds to our knowledge concerning this significant contemporary phenomenon. Previous studies have already pointed to the importance of rhetoric and discourse in contexts such as mergers and acquisitions (Vaara 2002; Vaara and Tienari 2002; Comtois et al. 2004). Nevertheless, we think that our analysis increases our understanding of the crucial role of the media in influencing how different stakeholders make sense of and consequently react to such events. 
Moreover, we think that this analysis also contributes to the discussions around legitimacy more generally (e.g. Van Leeuwen and Wodak 1999). Our study can be seen as one of few empirical analyses of discursive legitimation strategies and a specific kind of extension of Van Leeuwen's pioneering work. In particular, students of CDA can benefit from our model linking the textual legitimating strategies and journalistic practices in the media context.

Nevertheless, this analysis is in several ways only a beginning, and poses further questions to be taken seriously in future research. Each type of legitimation strategy deserves more focused attention. It would be extremely interesting, for example, to study further the role of exemplarity, examine the various ways authorities are established, analyze how dominant and alternative rationalizations and moralizations are developed and used, and examine in more detail the various kinds of mythopoetic elements in contemporary management and organization discourse. One could also go further in detailed analysis of genres and genre chains in contemporary business news and examine the particular mix of discourses associated with them. Also, we have not analyzed the social practices of business journalism in detail in this paper. Looking at the specific professional and other practices within this emerging social field, and power relationships between different actors, is, however, of fundamental importance if we want to understand the broader social conditions and implications of business journalism. In analyzing legitimation, one should also take the consumption side seriously. Analyzing these processes in detail requires specific research settings and innovative methods. Nevertheless, it would be extremely important to examine how people consume the texts, and the ways in which this does or does not correspond to the initial - often vague intentions of the journalists.

\section{References}

Aldrich, Howard E., and C. Marlene Fiol 1994 'Fools rush in? The institutional context of industry creation'. Academy of Management Review 19/4: 645-670. 
Alvesson, Mats, and Dan Kärreman 2000 'Varieties of discourse: On the study of organizations through discourse analyses'. Human Relations 53/9: 1125-1151.

Arndt, Margarete, and Barbara Bigelow 2000 'Presenting structural innovation in an institutional environment: Hospitals' use of impression management'. Administrative Science Quarterly 45/3: 494-524.

Ashforth, Blake E., and Barrie W. Gibbs 1990 'The double-edge of organizational legitimation'. Organization Science 1/2: 177-194.

Berger, Peter, and Thomas Luckmann 1966 The social construction of reality. Garden City, NY: Doubleday.

Bourdieu, Pierre 1998 On television. New York: The New Press.

Brown, Andrew D. 1998 'Narrative, politics and legitimacy in an IT implementation'. Journal of Management Studies 35/1: 35-58.

Brown, Andrew D., and Matthew R. Jones 2000 'Honorable members and dishonourable deeds: Sensemaking, impression management and legitimation in the "Arms of Iraq Affair". Human Relations 53/5: 655-690.

Comtois, Elise, Jean-Louis Denis, and Ann Langley 2004 'Rhetorics of efficiency, fashion and politics: Hospital mergers in Quebec'. Management Learning 35/3: 303-320.

Creed, Douglas, Maureen Scully, and John Austin 2002 'Clothes make the person? The tailoring of legitimating accounts and the social construction of identity'. Organization Science 13/5: 475-496.

Dowling, J., and Jeffrey Pfeffer 1975 'Organizational legitimacy: Social values and organizational behavior'. Pacific Sociological Review 18/1: 122-136. 
Dunford Richard, and Ian Palmer 1996 'Metaphors in popular management discourse: The case of corporate restructuring' in Metaphor and organizations. D. Grant and C. Oswick (eds), 96-109. London: Sage.

Elsbach, Kimberley, and Robert I. Sutton 1992 'Acquiring organizational legitimacy through illegitimate actions: A marriage of institutional and impression management theories'. Academy of Management Journal 35/4: 699-738.

Fairclough, Norman 1995 Media discourse. London: Edward Arnold.

Fairclough, Norman 1997 Critical discourse analysis: The critical study of language. London: Longman.

Fairclough, Norman 2000 'Language and neoliberalism' (Guest editorial). Discourse and Society 11/2: 147-148.

Fairclough, Norman 2003 Analysing discourse: Textual analysis for social research. London: Longman.

Fairclough, Norman, and Wodak, Ruth 1997 'Critical discourse analysis' in Discourse as social interaction. T. van Dijk (ed.), 258-284. London: Sage.

Foucault, Michel 1980 Power/knowledge. Brighton: Harvester.

Giddens, Anthony 1984 The constitution of society. Cambridge: Polity.

Grant, David, Tom Keenoy, and Cliff Oswick editors 1998 Discourse and organization. London: Sage. 
Grant, David, Cynthia Hardy, Cliff Oswick, and Linda Putnam editors 2004 Organizational discourse. London: Sage.

Habermas, Jürgen 1975 Legitimation crisis. Boston, MA: Beacon Press.

Hardy, Cynthia, and Nelson Phillips 1998 'Strategies of engagement: Lessons from the critical examination of collaboration and conflict in an interorganizational domain'.Organization Science 9/2: 217-230.

Hardy, Cynthia, David Grant, Tom Keenoy, Cliff Oswick, and Nelson Phillips editors 2004 Organization Studies 25/1: Special issue on 'Organizational discourse'.

Hybels, Ralph C. 1995 'On legitimacy, legitimation, and organizations: A critical review and integrative theoretical model'. Academy of Management Best Papers Proceedings, $241-245$.

Kitchener, Martin 2003 'Mobilizing the logic of managerialism in professional fields: The case of academic health care mergers'. Organization Studies 23/3: 391-420.

Kostova, Tatiana, and Srilata Zaheer 1999 'Organizational legitimacy under conditions of complexity: The case of the multinational enterprise'. Academy of Management Review 24/1: 64-81.

Lamertz, Kai, and Joel A. C. Baum 1998 'The legitimacy of organizational downsizing in Canada: An analysis of explanatory media accounts'. Canadian Journal of Administrative Sciences 15/1: 93-107.

Laurila, Juha, and Minna Ropponen 2003 'Institutional conditioning of foreign expansion: Some evidence from Finnish-based paper industry firms, 1994-2000'. Journal of Management Studies 40/3: 721-747. 
Lawrence, Thomas B., Nelson Phillips, and Cynthia Hardy 1999 'Watching whale watching: Exploring the discursive foundations of collaborative relationships'. Journal of Applied Behavioral Science 35/4: 479-502.

Mazza, Carmelo, and José Luis Alvarez 2000 'Haute couture and pret-à-porter. The popular press and the diffusion of management practices'. Organization Studies 21/3: $567-588$.

Phillips, Nelson, and Cynthia Hardy 2002 Discourse analysis: Investigating processes of social construction. Thousand Oaks, CA: Sage.

Rojo, Luisa Martin, and Teun van Dijk 1997 "There was a problem, and it was solved!" Legitimating the expulsion of "illegal" migrants in Spanish parliamentary discourse'. Discourse and Society 8/4: 523-566.

Scott, Richard 1995 Institutions and organizations. Thousand Oaks, CA: Sage.

Suchman, Mark C. 1995 'Managing legitimacy: Strategic and institutional approaches'. Academy of Management Review 20/3: 729-757.

Vaara, Eero 2002 'On the discursive construction of success/failure in narratives of postmerger integration'. Organization Studies 23/2: 213-250.

Vaara, Eero, and Janne Tienari 2002 'Justification, legitimization and naturalization of mergers and acquisitions: A critical discourse analysis of media texts'. Organization 9/2: 275-303.

Vaara, Eero, and Janne Tienari 2004 'Critical discourse analysis as a methodology for international business studies' in Handbook of qualitative research methods for international business. R. Marschan-Piekkari and C. Welch (eds), 342-359. 
Cheltenham: Edward Elgar. Van Dijk, Teun 1990 News as discourse. Hillsdale, NJ: Lawrence Erlbaum. Van Dijk, Teun 1997 Discourse studies: A multidisciplinary introduction, Vols 1 and 2. London: Sage.

Van Dijk, Teun 1998 Ideology: A multidisciplinary approach. London: Sage.

Van Leeuwen, Theo 'The grammar of legitimation'. Unpublished manuscript. Van Leeuwen, Theo, and Ruth Wodak 1999 'Legitimizing immigration control: A discoursehistorical perspective'. Discourse Studies 1/1: 83-118.

Watson, Tony J. 1998 'Managerial sensemaking and occupational identities in Britain and Italy: The role of management magazines in the process of discursive construction'. Journal of Management Studies 35/3: 285-301.

Westwood, Robertz, and Stephen Linstead 2001 The language of organization. London: Sage.

Wodak, Ruth 2004 'Critical discourse analysis' in Qualitative research practice. C. Seale, G. Gobo, J. F. Gubrium and D. Silverman (eds), 197-213.

London: Sage. Wodak, Ruth, and Michael Meyer 2002 Methods of critical discourse analysis. London: Sage.

Wodak, Ruth, Rudolf de Cillia, Martin Reisigl, and Karin Liebhart 1999 The discursive construction of national identity. Edinburgh: Edinburgh University Press.

Zimmerman, Monica A., and Gerald J. Zeitz 2002 'Beyond survival: Achieving new venture growth by building legitimacy'. Academy of Management Review 27/3: 414-443. 


\section{Eero Vaara}

Eero Vaara is Professor of Management and Organization at the Swedish School of Economics and Business Administration in Helsinki, Finland, and Visiting Professor at Ecole de Management de Lyon, France. His research interests focus on organizational change, industrial restructuring, and globalization. He has lately worked especially on narrative and discursive perspectives and philosophical questions in organization and management research. His work has been published in leading international journals.

Address: Management and Organization, Swedish School of Economics and Business Administration, PO Box 479, FIN-00101 Helsinki, Finland.

Email: eero.vaara@hanken.fi

\section{Janne Tienari}

Janne Tienari is Professor of Management and Organizations at Lappeenranta University of Technology, Finland. His research interests include cross-cultural studies of gender and organizing, mergers and acquisitions, media discourse, and the diffusion and translation of management ideas and practices. His work has been published in leading international journals such as Organization Studies, Journal of Management Studies, Organization, Human Relations, Scandinavian Journal of Management, Journal of Management Inquiry, and Gender, Work and Organization.

Address: Department of Business Administration, Lappeenranta University of Technology, PO Box 20, FIN-53851 Lappeenranta, Finland.

Email: janne.tienari@lut.fi

Juha Laurila

Juha Laurila is Professor of Management and Organization at the Helsinki School of Economics, Finland. He is the author of Managing Technological Discontinuities (1998 London: Routledge) and co-editor of Technological Change and Organizational Action (2003 London: Routledge). His articles have appeared in the Journal of Management Studies, Organization Studies, and other journals. His current research interests include institutional and social movement theory and historical research on change in firms and industries.

Address: Helsinki School of Economics, Runeberginkatu 14-16, PO Box 1210, FIN00101 Helsinki, Finland.

Email: juha.laurila@hse.fi 